School of Population Health, University of New South Wales, Sydney (UNSW Sydney), New South Wales, Australia

2 Medical School, Australian National University, Canberra, Australian Capital Territory, Australia

Correspondence to: P L Simpson p.simpson@unsw.edu.au Cite this as: BMJ 2021;373:n859 http://dx.doi.org/10.1136/bmj.n859 Published: 07 April 2021

\section{Incarcerated people should be prioritised for covid-19 vaccination}

\author{
Vaccination is essential for this vulnerable group, and the civil society around them
}

\author{
Paul L Simpson, ${ }^{1}$ Michael Levy, ${ }^{2}$ Tony Butler ${ }^{1}$
}

In most countries, the covid-19 infection rate is consistently higher in prisons than in the community, including those with the largest prison systems: China, India, and the United States. ${ }^{1}$ Many of the largest cluster outbreaks in the US have occurred in prisons. After mass testing in April 2020 at Ohio's Marion Correctional Institute, covid-19 was detected in $79 \%$ of prisoners (1950 of 2453 ) and $35 \%$ of prison staff (154 of 446) within three weeks of the first reported case. ${ }^{2}$ This outbreak was consistent with a reproduction rate greater than 14 if covid-19 was introduced to the institute by a single person. ${ }^{2}$ The covid-19 case rate in the prisoner population in the US was estimated to be 5.5 times that of the general population. ${ }^{3}$

Prisons and detention centres have two characteristics that lead to them being described as "epidemiological pumps"-high population density confinement and porous borders between the confined population and the community, crossed daily by staff. ${ }^{4}$ Prison crowding and the health and age profiles of incarcerated populations exacerbate covid-19 morbidity and mortality risk. Almost 60\% of countries worldwide have prisoner populations that exceed their design capacity, with the density of people housed in each prison cell directly linked to transmission of respiratory infectious diseases. ${ }^{5}$

Epidemiological surveys of prisoners consistently find high rates of chronic health conditions such as hypertension, asthma, and tuberculosis. ${ }^{6}$

Additionally, the number of older people in prisons in many developed countries, typically defined as 55 years or older because of accelerated ageing, ${ }^{7}$ has greatly increased. ${ }^{6}$ Prison alternatives for the sizeable proportion of pretrial detainees would help reduce overcrowding. 5

Since the pandemic began, political leaders have emphasised that their control measures are informed by expert medical and public health advice. The World Health Organization recommends that people living and working in prisons and detention centres be prioritised for covid-19 vaccination if a country, territory, or area has high rates of community transmission or if clusters of cases are detected locally. ${ }^{8}$ Yet countries with the highest community transmission rates, including England, India, the US, and Australia (which has experienced clusters of cases), have not heeded WHO's advice. ${ }^{9}$

Whether incarcerated people should be a vaccine priority group presents a dilemma for governments. Canadian and South African governments, which classify prisoners as a priority group, have met with criticism from conservative politicians and custodial staff representatives who oppose this measure. Colorado discarded the recommendation of its experts to prioritise prisoners after a media backlash claiming that criminals were "jumping the queue" ahead of healthcare workers and older people. ${ }^{9}$ Similarly, the Australian government rejected the recommendation of its technical advisory group to prioritise residents in correctional and detention facilities, ${ }^{10}{ }^{11}$ whereas Israel's attorney general had to intervene to direct the prison service to begin vaccinating prisoners after their initial refusal to carry out a Ministry of Health directive to do so. ${ }^{9}$

Although prisoner vaccination in Canada, Northern Ireland, and Israel has started, their governments have chosen an equality approach, which considers only older people (Israel, Northern Ireland) or older people with health conditions (Canada, Northern Ireland) in prisons as a priority, in line with their strategies for people outside prison. ${ }^{9}$ But this approach overlooks the unique factors associated with incarcerated people, which place them and their civil society contacts at substantial risk of covid-19 infection, transmission, and death. The confined settings in which people are incarcerated is a compelling reason to provide all such people, as well as prison staff, with high efficacy vaccines, and we urge all governments to implement WHO's recommendation as a matter of urgency.

Prioritising incarcerated people while vaccines are scarce might be unpopular. But this does not justify ignoring scientific advice by WHO or government advisory groups-advice based on the best available empirical evidence, interpreted by experts. The extent of media criticism or social unrest will probably depend on how effectively governments communicate their decision making to the public. ${ }^{12}$ Such communication should emphasise two key messages. Firstly, including incarcerated people in public health responses to covid-19 benefits the wider community. ${ }^{13}$ Secondly, such an approach is a commitment to human rights and a more just society.

Achieving positive health outcomes for all, not just equal access to healthcare, is embedded in our understanding of justice. Historically, this understanding helped to drive successful interventions against HIV/AIDS, by recognising and protecting the human rights (including the right to treatment) of stigmatised groups at highest risk. ${ }^{14}$ When reflecting on whether incarcerated populations should be prioritised for covid-19 vaccination, it is perhaps appropriate to give the last word to Nelson Mandela, who wrote that "no one truly knows a nation until one has been inside its jails. A nation should not be judged by how it treats its highest citizens, but its lowest ones." 15

Provenance and peer review: Not commissioned; externally peer reviewed. 
Competing interests: We have read and understood BMJ policy on declaration of interests and declare the following interests: none.

1 Byrne J, Rapisarda SS, Hummer D, Kras KR. An imperfect storm: identifying the root causes of covid-19 outbreaks in the world's largest corrections systems. Vict Offenders 2020;15:862-909doi: 10.1080/15564886.2020.1838373.

2 KhudaBukhsh WR, Khalsa SK, Kenah E, Rempala GA, Tien JH. Covid-19 dynamics in an Ohio prison.medRxiv2021.01.14.21249782. https://www.medrxiv.org/content/10.1101/2021.01.14.21249782v1

3 Saloner B, Parish K, Ward JA, DiLaura G, Dolovich S. Covid-19 cases and deaths in federal and state prisons. JAMA 2020;324:602-3. doi: 10.1001/jama.2020.12528 pmid: 32639537

4 Coker R. Report on coronavirus and immigration detention. 2020. https://detentionac tion.org.uk/wp-content/uploads/2020/03/Report-on-Detention-and-COVID-Final-1.pdf

5 Simpson PL, Butler TG. Covid-19, prison crowding, and release policies. BMJ 2020;369:m1551. doi: 10.1136/bmj.m1551 pmid: 32312733

6 Fazel S, Baillargeon J. The health of prisoners. Lancet 2011;377:956-65 doi: 10.1016/S0140-6736(10)61053-7 pmid: 21093904

7 Greene M, Ahalt C, Stijacic-Cenzer I, Metzger L, Williams B. Older adults in jail: high rates and early onset of geriatric conditions. Health Justice 2018;6:3. doi: 10.1186/s40352-018-0062-9 pmid: 29455436

8 World Health Organization. World Health Organization SAGE Roadmap for prioritizing the use of ccovid-19 vaccines in the context of limited supply. Version 1.1. 13 Nov 2020.

https://www.who.int/publications/m/item/who-sage-roadmap-for-prioritizing-uses-of-covid-19vaccines-in-the-context-of-limited-supply

9 Institute for Crime and Justice Policy Research. International news and guidance on covid-19 and prisons: 1 December onwards. 2021. https://www.prisonstudies.org/news/international-newsand-guidance-covid-19-and-prisons-1-december-onwards.

10 Australian Government. Australian covid-19 vaccination policy. 2020 https://www.health.gov.au/node/18777/australias-covid-19-vaccination-policy

11 Australian Technical Advisory Group on Immunisation. Preliminary advice on general principles to guide the prioritisation of target populations in a covid-19 vaccination program in Australia 2020. https://www.health.gov.au/resources/publications/atagi-preliminary-advice-on-generalprinciples-to-guide-the-prioritisation-of-target-populations-in-a-covid-19-vaccination-programin-australia

12 Lee $\mathrm{C}$. How do we choose who gets the flu vaccine in a pandemic-paramedics, prisoners, or the public? Conversation May 2017. https://theconversation.com/how-do-we-choose-who-getsthe-flu-vaccine-in-a-pandemic-paramedics-prisoners-or-the-public-74164.

13 Kinner SA, Young JT, Snow K, etal. Prisons and custodial settings are part of a comprehensive response to COVID-19. Lancet Public Health 2020;5:e188-9.

doi: 10.1016/S2468-2667(20)30058-X pmid: 32197116

14 Brandt AM. How AIDS invented global health. N Engl / Med 2013;368:2149-52. doi: 10.1056/NEJMp1305297 pmid: 23738542

15 Mandela N. Long walk to freedom: the autobiography of Nelson Mandela. Little, Brown, and Company, 1994

This article is made freely available for use in accordance with BMJ's website terms and conditions for the duration of the covid-19 pandemic or until otherwise determined by BMJ. You may use, download and print the article for any lawful, non-commercial purpose (including text and data mining) provided that all copyright notices and trade marks are retained. 